\title{
FAMÍLIA, TERRA E PODER POLÍTICO NO MUNÍCIPIO DE CUITÉ (PB)
}

\author{
Valesca Marques Cavalcanti ${ }^{1}$ \\ (iD) \\ ttps://orcid.org/0000-0001-8188-583X \\ Luis Henrique Cunha ${ }^{2}$ \\ https://orcid.org/0000-0003-3002-8277
}

\section{RESUMO}

No município de Cuité, no Curimataú Paraibano, as famílias Pereira, Venâncio dos Santos, Fonseca, Furtado e Simões dominaram a política local desde o final do século XIX até o início do século XXI, ao mesmo tempo em que, a partir da década de 1950, assistiram à fragmentação das grandes fazendas das quais eram proprietárias no passado. Este artigo, retomando um tema clássico nas ciências sociais brasileiras, analisa as relações entre família, política e propriedade fundiária, considerando como os descendentes da elite cuiteense vivenciaram os dilemas da herança familiar, num contexto de modernização das relações sociais e econômicas. A fragmentação da grande propriedade foi considerada dentro de um quadro de oportunidades econômicas, disputas políticas e também da adoção de novas estratégias de reprodução social das famílias da elite local. Entre alianças e rivalidades políticas, destaca-se o "movimento diaspórico" de grande parte dos descendentes destas linhagens, processo que expressa os investimentos realizados por estas famílias na educação formal dos filhos, direcionados para o exercício de profissões liberais e no serviço público em centros urbanos maiores.

Palavras-chave: Elites, Diáspora, Grande Propriedade Rural, Poder Local.

\section{FAMILY, LAND PROPERTY AND POLITICAL POWER IN A SMALL CITY IN BRAZIL}

\begin{abstract}
In Cuité, a small city in Paraíba state, Brazil, the Pereira, Venâncio dos Santos, Fonseca, Furtado and Simões families dominated local politics from the end of the 19th century to the beginning of the 21 st century. From the 1950s onwards, they saw the fragmentation of the large land properties that they owned in the past. This article, resuming a classic theme in the Brazilian social sciences, analyzes the relationships between family, politics and land ownership, considering how the descendants of this elite experienced the dilemmas of family inheritance, in a context of modernization of social and economic relations. The fragmentation of large land property was considered within the framework of economic opportunities, political disputes and also the adoption of new strategies for social reproduction of the families of the local elite. Among alliances and political rivalries, the "diasporic movement" of most of the descendants of these lineages stands out, a process that expresses the investments made by these families in the formal education of their members, directed to the exercise of liberal professions and public service in larger urban areas.
\end{abstract}

Key words: Elites, Diaspora, Large Land Property, Local Power.

\section{FAMILIA, TIERRA Y PODER POLÍTICO EN EL MUNICIPIO DE CUITÉ (PB)}

\section{RESUMEN}

En el municipio de Cuité, en Curimataú Paraibano, las familias Pereira, Venâncio dos Santos, Fonseca, Furtado y Simões dominaron la política local desde finales del siglo XIX hasta principios

\footnotetext{
${ }^{1}$ Doutora em Ciências Sociais (UFCG). E-mail: valescacavalcanti@gmail.com.

${ }^{2}$ Doutor em Desenvolvimento Socioambiental (UFPA) e professor do Programa de Pós-Graduação em Ciências Sociais (UFCG). E-mail: luishcunha@uol.com.br.
} 
del XXI, al mismo tiempo que, a partir de 1950 asistieron la fragmentación de las grandes haciendas que poseían en el pasado. Este artículo, retomando un tema clásico de las ciencias sociales brasileñas, analiza las relaciones entre familia, política y propiedad de la tierra, considerando cómo los descendientes de la élite cuiteense vivieron los dilemas de la herencia familiar, en un contexto de modernización de las relaciones sociales y económicas. La fragmentación de la gran propiedad fue considerada a partir del marco de las oportunidades económicas, las disputas políticas y también la adopción de nuevas estrategias de reproducción social de las familias de la élite local. Entre las alianzas y rivalidades políticas, se ha destacado el "movimiento diaspórico" de la mayoría de los descendientes de estos linajes, proceso que expresa las inversiones que realizan estas familias en la educación formal de sus hijos, dirigida al ejercicio de profesiones liberales y de servicio público en centros urbanos mayores.

Palabras-clave: Élites, Diáspora, Gran Propiedad Rural, Poder Local.

\section{INTRODUÇÃO}

Na literatura acadêmica e no imaginário social, o poder oligárquico das elites políticas nos municípios do interior do Nordeste foi, frequentemente, associado à grande propriedade fundiária, que seria responsável, também, pela persistência no tempo do poder político de certos "grupos de base familiar" (Rêgo, 2008; Furtado 1967; Garcia Junior, 2007; Nunes, 2016; Monteiro, 2016; Maia, 2013; Menezes, 2018; entre outros). Rêgo (2008, p. 14-15), em seu estudo sobre família e coronelismo no Brasil, em que analisa o caso dos Heráclito do Rêgo, afirma que "relações de parentesco são sempre definidas em função de um patrimônio": de um lado, o "eixo fundiário, de outro o eixo de sangue". Ele parte, assim, do pressuposto de que o "conceito de família se fundamenta na propriedade e na herança".

Lewin (1993), em seu clássico sobre Política e Parentela na Paraíba, autonomiza a esfera política, apreendo-a em sua dinâmica própria, sem estabelecer uma relação automática entre elites políticas e elites fundiárias. Segundo ela, "a maior parte dos estudiosos apenas mencionou a tradicional dependência da organização política brasileira com relação à família e aos laços de parentesco sem atribuir importância central às implicações daquela relação através do tempo" (Lewin, 1993, p. 8).

Neste artigo, retomamos este debate, partindo do pressuposto de que a relação entre propriedade da terra e poder local no Nordeste pode ser problematizada para além destas duas posições. Em Cuité, município localizado na microrregião do Curimataú Ocidental da Paraíba, com 20.348 habitantes (IBGE, 2017), é possível estabelecer uma relação entre famílias proprietárias e elites políticas locais, mas essa relação não é automática nem mesmo constante no tempo. Assim, o monopólio da propriedade da terra e o papel dos laços de parentesco no poder local são explorados como dimensões distintas, ainda que interconectadas, do poder político e do status familiar das elites locais. 
A pesquisa que fundamenta este artigo ${ }^{3}$ estudou as famílias Venâncio dos Santos, Furtado, da Costa Pereira, Fonseca e Simões, que monopolizaram o cenário político, econômico e social no município ao longo do século XX e início do século XXI. Destas famílias, saíram quase a totalidade dos prefeitos da história de Cuité. Uma marca importante da trajetória destas famílias é a dissolução do patrimônio fundiário registrada nas últimas quatro ou cinco décadas, enquanto na esfera política a influência social destas elites continua até os dias atuais, alternando rivalidades e alianças que se perpetuam no tempo e são permanentemente atualizadas.

Para tanto, adotamos diferentes estratégias de pesquisa: a) a análise do processo de dissolução do patrimônio fundiário das famílias estudadas a partir da década de 1950, com base em dados secundários (IBGE e INCRA) e pesquisa nos inventários judiciais; b) a apreensão do monopólio destas famílias sobre os principais cargos políticos no município a partir de 1937, quando o município é emancipado, até as eleições municipais de 2016; c) a construção de árvores genealógicas orientadas pela ocupação de cargos políticos locais, que permitiu analisar a dinâmica intrafamiliar de transmissão da influência política entre as gerações e também as complexas imbricações entre estas diferentes famílias; e d) uma investigação sobre os esforços recentes de produzir uma história política municipal, empreendida por membros destes grupos familiares, através principalmente da construção de narrativas relacionadas a alguns personagens mais destacados.

Quanto à dissolução do patrimônio fundiário, pudemos constatar que entre as famílias Furtado, Venâncio dos Santos, da Costa Pereira, Fonseca e Simões, o patrimônio fundiário sofreu intensa fragmentação. Segundo dados do INCRA e INTERPA, é possível demonstrar a fragmentação da grande propriedade a partir da década de 1950, chegando a ocupar atualmente apenas $08 \%$ da área total dos estabelecimentos agropecuários, numa região que concentra o maior número de operações do Programa Nacional de Crédito Fundiário na Paraíba.

Membros das famílias Furtado, Venâncio dos Santos, da Costa Pereira, Fonseca e Simões dominaram a política local em todo o período analisado. Do total de 25 prefeitos eleitos ou nomeados a partir de 1937, 16 eram destas famílias, com destaque para a rivalidade entre as famílias da Costa Pereira e Venâncio dos Santos, originada num episódio em 1904, que levou ao rebaixamento de Cuité à vila da comarca de Picuí, rivalidade que permanece até os dias atuais. Além disso, também foram dominantes no legislativo. Nas eleições de $2016^{4}$, o cargo de prefeito foi disputado entre Fabiano Valério de Farias Fonseca (48,03 \%, ou 6.365 votos), apoiado pelos Venâncio dos Santos e Furtado, e Charles Cristiano Inácio da Silva (eleito com 51,97\%, 6.887

\footnotetext{
${ }^{3}$ Que deu origem à tese de doutorado intitulada "Família, política e propriedade fundiária: os dilemas da herança entre membros da elite no município de Cuité (PB)", defendida em fevereiro de 2019, por Valesca Marques Cavalcanti, junto ao Programa de Pós-Graduação em Ciências Sociais da Universidade Federal de Campina Grande.

${ }^{4}$ Disponível em: https://www.eleicoes2016.com.br/. Acesso em 30/04/2019.
} 
votos), apoiado pelos Pereira, reeleito em 2020. O presidente da Câmara Municipal no período 2019-2020 foi Renan Teixeira dos Santos Furtado, que é bisneto de Jeremias Venâncio dos Santos, ex-prefeito e neto de Cláudio Gervásio Furtado, também ex-prefeito. Em 2020, Renan Furtado foi eleito vice-prefeito de Cuité.

A partir das árvores genealógicas, pudemos observar que as disputas eleitorais no município de Cuité permanecem atreladas às famílias tradicionais e a suas rivalidades. Contudo, entre rupturas e permanências, não é possível desconsiderar as transformações recentes no cenário político, social e econômico do país e da região. Processos de modernização ressignificam permanentemente a influência política destas famílias, que precisam mudar suas estratégias eleitorais e suas alianças. $\mathrm{O}$ uso desse recurso metodológico mostrou também que a descendência política em Cuité não segue uma única linha. Nas últimas décadas, até em virtude da saída dos filhos das principais lideranças nos anos 1950 e 1960, outros ramos destas famílias ascenderam ao poder local. E as alianças políticas entre famílias expressa também alianças matrimoniais.

A análise das narrativas empreendidas a partir da década de 1990, que interpretamos como um esforço de produzir uma história política do município, revela o esforço de localizar o status da família no presente com referência ao passado (Bottero, 2005; 2012), mas esse esforço minimiza a condição de grandes proprietários, e foca principalmente as realizações dos membros das famílias na esfera política.

Este trabalho é herdeiro da obra seminal de Lewin (1993) e integra os esforços de um grupo de pesquisadores do PPGCS/UFCG no sentido de considerar as transformações na estrutura fundiária e os processos de modernização mais amplos para refletir sobre o poder político nesta região. A história das famílias de elite de Cuité mostra que a conversão de capital econômico e político em capital cultural foi a estratégia dominante entre linhagens proeminentes a partir da década de 1950. Os filhos dos líderes políticos, personagens até os dias de hoje exaltados, foram socializados não para a terra ou para a política, mas para o exercício de profissões liberais em centros urbanos mais desenvolvidos. As motivações que levaram a priorização desta estratégia precisam ainda ser melhor analisadas, mas acreditamos que este artigo contribui para complexificar a compreensão sobre reprodução familiar do poder local em pequenos municípios do interior do Nordeste.

\section{FAMÍLIAS DA ELITE NO MUNICÍPIO DE CUITÉ - PB}

Scott (2010) afirma que a palavra elite é um dos termos mais genéricos dentre os usados em estudos descritivos e que quase todo grupo ou categoria de pessoas poderosas, favorecidas, qualificadas, privilegiadas ou superiores é chamado de elite. Segundo o autor, é necessário restringir 
o conceito para "considerar que as elites são distintas de outros tipos de grupo social por serem grupos que detêm tipo especial de poder" (Scott, 2010, p. 75).

Segundo Perissinotto (2009), para Wright Mills a elite do poder é formada pelo conjunto de indivíduos que ocupava o topo das ordens institucionais (militar, econômica e política). E acrescenta que, para estudar esse grupo, Wright Mills analisou sua origem social, sua trajetória escolar e profissional, e constatou a íntima relação existente entre seus membros.

Para Bourdieu (1989), a teoria sociológica deve promover uma ruptura com a visão essencialista encontrada em pesquisas influenciadas pela problemática das elites e pelos adeptos do método prosopográfico ${ }^{5}$. A teoria das elites tenderia a naturalizar as propriedades sociais distintivas dos grupos dominantes, como se fossem recursos inerentes à superioridade inata de seus membros. Para romper com este modo de pensamento, Bourdieu (1989) vai empregar o termo campo de poder, e o entende como campo de relações de forças entre as posições sociais que garantem aos seus ocupantes um quantum suficiente de força social - ou de capital -, de modo que estes tenham a possibilidade de entrar nas lutas pelo monopólio do poder (Perissinoto, 2009). Ainda que o argumento de Bourdieu seja importante, é possível apropriar-se de algumas de suas lições, sem abandonar o uso do termo, que remete a uma forma de representação do social reconhecível, ou seja, menos abstrato que a categoria campo de poder.

Saint Martin (2008) adota o conceito de elite proposto por Giovanni Busino, da década de 1990, em que o termo designa

todos aqueles que se encontram no topo da hierarquia social e aí exercem funções importantes, as quais são valorizadas e reconhecidas publicamente através de rendas importantes, diferentes formas de privilégio, de prestígio e de outras vantagens oficiais ou oficiosas (Busino apud Saint Martin, 2008, p.48).

Contudo, segundo a autora:

As elites não consistem unicamente na soma do conjunto dos grupos ou dos atores que ocupam posições dominantes nos domínios político, econômico e administrativo e não são apenas uma categoria da estratificação social; elas propõem modelos de comportamento, possuem sistemas de valores e interesses, constituem grupos de influência e, às vezes, de pressão. (Saint Martin, 2008, p. 48-49)

Klüger (2017), influenciado por Bourdieu, critica a falta de contextualização social dos agentes e dos laços tecidos entre eles em alguns trabalhos dedicados a uma sociologia das elites, influenciada pelas teorias das redes. Também apresenta duas vias de estudos na área de sociologia

\footnotetext{
5“A prosopografia é a investigação das características comuns do passado de um grupo de atores na história por meio do estudo coletivo de suas vidas. O método empregado consiste em definir um universo a ser estudado e então a ele formular um conjunto de questões padronizadas - sobre nascimento e morte, casamento e família, origens sociais e posições econômicas herdadas, local de residência, educação e fonte de riqueza pessoal, religião, experiência profissional e assim por diante" (Stone, apud Perissinoto, 2008, p. 10).
} 
das elites que propõem a conciliação das duas metodologias, a primeira delas aqui intitulada "da rede ao espaço social" e a segunda denominada "do espaço social às redes".

Para os propósitos deste trabalho, parece-nos adequado o uso do termo elite para fazer referência às famílias que monopolizaram patrimônio fundiário e poder político no município de Cuité ao longo do Século XX. Tanto em termos de posição social quanto de reputação social, e mesmo dos laços (sejam eles de cooperação e aliança ou de disputa política e competição social) que os membros destas famílias estabelecem entre si, é possível caracterizá-los como os elementos nucleares da elite local.

A partir do conceito de elite, é possível definir as famílias da Costa Pereira, Venâncio dos Santos, Furtado, Fonseca e Simões como compondo a elite de Cuité (PB) no final do século XIX e ao longo dos Séculos XX e XXI, com influência tanto na vida pública quanto na vida privada, sobretudo, ao ocuparem, simultaneamente, posições dominantes em diferentes setores econômico, político, social, administrativo e cultural do município durante várias décadas.

Existia, por um lado, uma pequena camada de grandes proprietários, e, por outro, grande parte da população que não era proprietária. Este tecido social se modificou, nesta região, devido ao impacto das transformações econômicas que levaram a uma reorganização e ressignificação da terra, e a outras mudanças sociais, sobretudo modificações nos grupos sociais e, especificamente, no grupo familiar em que as mulheres passaram progressivamente a ser integradas no sistema educacional, aumentando a participação feminina também da força de trabalho, provocando reorganizações sociais, espaciais e temporais. O processo de urbanização e crise no setor rural provocou mudanças e marcou a trajetória dos grupos sociais no decorrer do século XX e início do século XXI.

Grandes propriedades somavam-se à influência social com o exercício de cargos importantes na comunidade. Os membros da elite disputavam entre si algumas destas posições destacadas, sendo percebidos pela população como grupos rivais no seio da elite local, rivalidade que se expressava especialmente nos períodos eleitorais. Em 29 de outubro de 1904, por exemplo, o rebaixamento de Cuité à vila da comarca de Picuí se deu em virtude da disputa entre membros das famílias Venâncio dos Santos e da Costa Pereira. Este episódio marcou a história política e social do município. As disputas entre as duas famílias se intensificaram após este acontecimento e, também, produziram uma rixa entre os municípios de Cuité e Picuí, afetando a sociabilidade entre os membros da comunidade e as disputas nos períodos eleitorais até os dias atuais.

Também é preciso desenvolver uma discussão sobre as transformações que os processos de modernização trouxeram ao setor agropecuário, percebendo que estas mudanças afetaram as relações entre as famílias rurais e as unidades de produção agropecuárias. Nas famílias mais abastadas, desenvolveu-se outro comportamento em relação à unidade de produção, sobretudo na 
alocação da força de trabalho de seus membros e, por outro lado, o investimento na educação levou alguns membros, homens e mulheres, a se deslocarem do campo para a cidade e a buscarem ocupações fora da zona rural. Assim, consideramos as transformações que colocam a família como uma unidade analítica importante, pois esta estabelece redes sociais, econômicas e políticas cuja lógica de funcionamento está interligada. O município de Cuité - PB tem em sua história alterações significativas provenientes desse momento marcado pela plantação do algodão e do sisal/agave, que possibilitou o enriquecimento de algumas famílias.

O aparecimento do algodão na região modifica a dinâmica de ocupação do Curimataú, que vai provocar mudanças na ocupação em Cuité, permitindo que as elites rurais transformem seus recursos simbólicos, culturais e econômicos com o objetivo de manter ou elevar sua posição social e de sua família.

Segundo Costa (1989), na região também se desenvolveu, paralelamente ao algodão, a produção da mandioca, que teve um aumento significativo nas primeiras décadas do século XX nos municípios de Cuité e Nova Floresta, ficando essa região conhecida como "A Serra da Farinha". No mesmo século, a região vai desenvolver a cultura do sisal e o município de Cuité será um grande produtor. Contudo, as culturas do algodão, da mandioca e do sisal passam por períodos de grandes crises e estes fatores vão alterar também a configuração dos proprietários, que vão ficar endividados e precisarão vender parte de seu patrimônio para pagar suas dívidas.

Somando-se as crises do algodão, mandioca e sisal, o patrimônio fundiário das famílias estudadas começou a sofrer modificações a partir das décadas de 70/80 do século XX, resultado, também da divisão dos bens após a morte dos patriarcas, o que influenciou a mobilidade social dos membros das famílias citadas.

Deste modo, para analisar as trajetórias destas famílias que faziam parte de uma elite local, é preciso pensar a evolução das unidades de produção, suas lógicas econômicas e sociais, uma vez que as suas implicações influenciaram e influenciam a distribuição e a organização de poder na comunidade.

As famílias dos grandes proprietários do munícipio de Cuité - PB migraram das fazendas para a cidade a partir das décadas de $1950^{6}$. "Contrariamente ao seu início, a segunda metade do século XX conhece um deslocamento das residências do campo para as cidades; já em 1980, 70\% da população se situam no polo urbano e, em 2000, praticamente $80 \%$ aí estão instalados" (Garcia Jr, 2007, p. 74), processo também vivenciado no município.

Dois elementos parecem marcar estas famílias a partir da segunda metade do Século XX: um lento deslocamento de seus descendentes para viverem em outras cidades, motivadas

\footnotetext{
${ }^{6}$ São exceções as famílias Venâncio dos Santos e Fonseca, que já estavam bem estabelecidas na sede municipal, em meados do Século XX, e que já por essa época não eram proprietários de grandes fazendas.
} 
inicialmente pelos investimentos na educação formal; e, mais recentemente, um processo de dissolução do patrimônio fundiário.

\section{FAMÍLIAS E POLÍTICA}

As análises relativas às interconexões entre famílias de elite, propriedade da terra e poder político em Cuité vão além da unidade de residência, isto é, família no sentido de grupos corresidentes e não corresidentes, interligados por vínculos de parentela consanguínea ou por alianças. Como também não devem orientar-se por uma relação automática entre elites políticas e elites fundiárias, como elemento essencial ao longo das décadas do Século XX, devendo ser observadas as profundas transformações ocorridas no espaço social em que estas famílias estão inseridas.

Lewin (1993), ao citar o grupo de base familiar, refere-se a este como uma unidade fundamental do sistema político informal. Segundo a autora:

(...) o núcleo dessa unidade de recrutamento e mobilização política compreendia os parentes mais próximos de seu chefe político: seus irmãos, os maridos de suas irmãs, os irmãos de sua mulher, seus tios e seus sobrinhos. Incluía também amigos políticos, desde muito tempo leais ao líder, o que lhes conferia um status de quase-parente. (Lewin, 1993, p. 22).

Ao destacar a parentela brasileira como uma modalidade sui generis de família, Rêgo (2008) utiliza o conceito de Maria Isaura de Queiroz, da obra O coronelismo numa interpretação sociológica, como um grupo de parentesco de sangue formado por várias famílias nucleares e algumas grandes vivendo cada uma em sua morada, e que podem se encontrar distantes uma das outras, sem quebrar os laços e as obrigações recíprocas. O autor também esclarece que, na condição de grupo, a família vai se apresentar sob os aspectos interligados do político, do econômico e do parentesco, e que as relações podem ser de aliança, competição ou rivalidade.

Linda Lewin (1993) também explica que, ao utilizar a expressão "de base familiar", evita confusão com os termos "oligarquia familiar" e "sistema familiar de domínio", pois a mobilização e o recrutamento da política paraibana não dependem exclusivamente do grupo de parentesco, visto que, para funcionar, ela dependia das relações essenciais que envolviam não-parentes.

Neste caso, optamos pela utilização do conceito de grupo de base familiar, conforme definido por Lewin (1993). Visto que, nas famílias estudadas, a captação e mobilização política era realizada por meio de relações que envolviam também grupos de não-parentes.

É preciso estudar as relações de parentesco como um conjunto de relações sociais estruturadas sobre as relações biológicas e a família, assim relações biológicas só são socialmente 
caracterizadas quando se confere uma expectativa na maneira de como as pessoas de um grupo têm que se portar em relação ao outro. A família, de acordo com Bourdieu (1996),

\begin{abstract}
(...) tem um papel determinante na manutenção da ordem social, na reprodução, não apenas biológica, mas social, isto é, na reprodução da estrutura do espaço social e das relações sociais. Ela é um dos lugares por excelência de acumulação de capital sob seus diferentes tipos e de sua transmissão entre as gerações: ela resguarda sua unidade pela transmissão e para a transmissão, para poder transmitir e porque ela pode transmitir. Ela é o "sujeito" principal das estratégias de reprodução. (Bourdieu, 1996, p. 131).
\end{abstract}

Ao estudarmos algumas famílias cuiteenses que ocuparam cargos políticos importantes no município e seus universos sociais, políticos, culturais e as relações que estabelecem por meio da interação social e pelo uso do capital simbólico, ou seja, um capital baseado no reconhecimento coletivo, é preciso esclarecermos que, , estas exerceram ou exercem a dominação não como efeito direto, mas, sim, indireto, por meio de um conjunto intricado de ações que se ligam por meio de suas limitações apresentadas pela estrutura do campo a qual pertence e que legitima a ordem simbólica incorporada.

As famílias Venâncio dos Santos, Fonseca, Simões, Furtado e da Costa Pereira iniciaram suas atividades políticas no século XIX, e algumas destas famílias seguem dando continuidade até hoje. Essas atividades se expressam no que se refere ao poder executivo e legislativo no município de Cuité, em vários mandatos, incluindo os membros ligados à família pelo casamento. Quase todos os políticos das famílias são, ou eram, parentes próximos. Nesses grupos de base familiar, registram-se posições político-partidárias divergentes e, também, antagônicas.

Segundo Rêgo (2008), paralelamente às atividades políticas, a família de Heráclito do Rêgo construiu um patrimônio e ocupou espaços econômicos, sociais e políticos, assim, para o autor, houve uma acumulação de seus capitais material e simbólico que assegurou a dominação, fundada na legitimidade que a sociedade lhe atribui que não está focada apenas na riqueza material, "mas, sobretudo à imagem construída para si mesma e transmitida às outras pessoas" (Rêgo, 2008, p. 18).

Em Cuité, as famílias analisadas se revezam no poder até os dias atuais, ainda que alguns destes grupos permanecem mais presentes que outros. Entre os prefeitos e vice-prefeitos cuiteenses ao longo do Século XX, encontram-se: Pedro Viana da Costa (1937 - ${ }^{\circ}$ Prefeito); João Venâncio da Fonseca (1937-1939); Jeremias Venâncio dos Santos (1940); Rivaldo Silvério da Fonseca (1940); Adauto Soares da Costa (1944-1945), casado com Amália da Fonseca da Costa; Benedito Venâncio dos Santos (1945-1946); Pedro Bento de Lima (1946-1947), casado com Alba Elita da Fonseca dos Santos Lima; Basílio Magno da Fonseca (1947-1951 - 1 Prefeito eleito); Pedro Simões Pimenta (1951-1955); Orlando Venâncio dos Santos (1955-1959); Jaime da Costa Pereira e o vice-prefeito Álvaro da Silva Furtado (1959 a 1963); Cláudio Gervásio Furtado e o vice-prefeito Gentil Venâncio dos Santos (1963 a 1968); Neusa Bezerra dos Santos (1968 a 1972), casada com Orlando Venâncio 
dos Santos; Cláudio Gervásio Furtado e o vice-prefeito Gentil Venâncio dos Santos Palmeira (1972 a 1977); Jaime da Costa Pereira Filho (1983 a 1988); vice-prefeito Osvaldo Venâncio dos Santos Filho (1993-1996); Osvaldo Venâncio dos Santos Filho (1997-2000 e 2001 a 2004); Euda Fabiana de Farias Palmeira Venâncio (2009 a 2012 e 2013 a 2016); e o vice-prefeito Eliú Javã Silva Santos Furtado (2017-2020).

É possível perceber que estas famílias se perpetuaram nos cargos políticos. Alguns membros são os que colocamos como membros mais destacados no mundo político, contudo, alguns de seus parentes de linhagens com menos destaque na esfera política começam a entrar no cenário político nas últimas décadas.

Também na câmara municipal de vereadores, os presidentes foram, em sua maioria, membros das famílias da Costa Pereira, Venâncio dos Santos, Simões, Fonseca e Furtado, vejamos: Ulisses Viana da Costa, Manuel da Silva Furtado Neto, Benedito Marinho da Costa, João Teodósio da Silva Coelho (casado com Joana Aurora da Silva Coelho, filha de Manuel Furtado da Silva), Cláudio Gervásio Furtado, José Bianor da Fonseca, Lourival de Lima Fialho (casado com Iracy Furtado Fialho), Leinaldo Simões Nobre, Maurílio Furtado Fialho, Giovanne dos Santos Furtado, Osvaldo Venâncio dos Santos Filho, Osvaldo Venâncio dos Santos, Fabiano Valério de Farias Fonseca, Eliú Javã Silva Santos Furtado e Renan Teixeira dos Santos Furtado.

Há ainda grandes proprietários de terras, como Pedro Simões Pimenta e seu filho Geraldo Simões, antigos donos das fazendas Retiro e Batentes (desapropriadas em 2001), totalizando mais de seis mil hectares, famosa pela casa sede, mata fechada onde caçavam onças e veados, inscrições rupestres e, atualmente, a construção do açude do Japi.

A partir destas informações, é possível identificar algumas famílias da elite em Cuité no final do século XIX e ao longo do Século XX, com destaque para as famílias da Costa Pereira, Venâncio dos Santos, Furtado, Fonseca e Simões. Estas famílias monopolizavam não apenas terra, mas também poder político e cargos administrativos. E, ainda hoje, pairam no imaginário local como famílias influentes. Membros destas famílias também tiveram mandatos como deputados e ocuparam cargos públicos, como juiz de direito da comarca, tabeliões de cartórios, diretores de escola, secretários do Município e do Estado, dentre outros.

\section{OCUPAÇÃO DE CARGOS POLÍTICOS PELAS FAMÍLIAS DA ELITE CUITEENSE}

A partir da ocupação de cargos políticos em Cuité, especialmente as funções executiva e legislativa, buscamos, neste artigo, analisar a influência das famílias de elite no poder local. Para isso, desenhamos árvores genealógicas e apresentaremos duas árvores das cinco famílias aqui estudadas: Fonseca e Venâncio dos Santos. Essas árvores não são completas, já que o interesse 
principal foi enfatizar aqueles membros destas linhagens que ocuparam cargos de prefeito e vereador (entre outros) ao longo dos Séculos XX e XXI. Adotamos a estratégia de refletir nos diagramas genealógicos as alianças matrimoniais entre estas famílias ao longo do tempo.

As genealogias aqui utilizadas, porém, não foram produzidas pelas próprias famílias da maneira como aparece neste artigo. Encontramos alguns esboços de construção de árvores genealógicas (Pereira Sobrinho, 2001, 2008) que nos ajudaram na elaboração dos diagramas, mas as árvores que virão a seguir são de elaboração própria, construídas a partir das questões postas por essa investigação. Como atesta Canêdo (2011, p. 58), "na sociedade ocidental, a descendência está assentada no poder masculino que se afirma por meio da patrilinearidade". Como, no caso em estudo, a ocupação de cargos políticos tem sido, até o momento, principalmente uma prerrogativa masculina - com exceção de Neusa Bezerra dos Santos (casada com Orlando Venâncio dos Santos), que ocupou o cargo de prefeita entre 1968-1972, e de Euda Fabiana Palmeira Venâncio (casada com Osvaldo Venâncio dos Santos Filho), também prefeita entre 2009 a 2012 - 2013 a 2016 -, optamos pela organização dos dados a partir da patrilinearidade.

Começamos investigando essas famílias e retornamos ao século XIX, no qual Sobrinho (2008) vai apresentar duas famílias como originárias do município e que denominou de: "Famílias descendentes do Olho d'Agua da Bica" e "Famílias descendentes da Volta". No Século XIX, segundo Sobrinho (2008), chega ao município uma viúva, natural de Acari, estado do Rio Grande do Norte, que se instalou próximo à fonte do Olho D'água da Bica e que se chamava Maria, apelidada de Dindinha (não foi possível descobrir seu cônjuge, de todo modo não chegou a residir em Cuité). Seus filhos eram Antônio Januário da Fonseca, Leopoldino Silvério dos Santos, João Alves Frazão Baraúna, Manuel Cardoso Fonseca de Mello, José Venâncio dos Santos, Targino José dos Santos e Alexandre Ferreira de Mello Pinto. Esta é a origem de duas das famílias que estudamos: Fonseca e Venâncio dos Santos, que, ao longo do Século XX, ainda que mantenham muitos vínculos, vão se constituir como duas linhagens distintas.

Já as "Famílias descendentes da Volta" remontam sua origem a Joaquim José da Costa e Maria Francisca de Medeiros, que, conforme consta em seu inventário instaurado em 1870, fornecido por José Pereira Sobrinho, tinha como filhos: Anacleto da Costa Pereira, Manoel do Nascimento Muribeca, Tomaz Soares da Costa Campos, Ivo Soares da Costa Jardim, Manuel Henriques da Costa, Luzia Renovatta de Medeiros, Justino Soares da Costa Pereira, Ana Theodora do Nascimento, Margarida Delfino da Costa, Joanna Baptista Monteiro e Ana Madalena da Conceição. A partir daí surge a linhagem dos da Costa Pereira.

Dos filhos de Dona Dindinha, ressaltamos na linhagem dos Fonseca: Antônio Januário da Fonseca, Leopoldino Silvério dos Santos, Manuel Cardoso Fonseca de Mello e José Venâncio dos Santos. Este último, porém, desempenha papel fundamental na instauração da linhagem dos 
Venâncio dos Santos. Dos filhos de Joaquim da Volta, destacamos Anacleto da Costa Pereira para o desenho da linhagem dos da Costa Pereira. Uma outra filha, Luzia Renovatta de Medeiros, casou com Leopoldino Silvério dos Santos, cuja filha, Maximina Leopoldino da Fonseca, casa-se com seu primo, Francisco Theodoro da Fonseca. Finalmente, Manuel Henriques da Costa, também filho de Joaquim da Volta, instaura a linhagem dos Henriques, em Picuí, que não foi diretamente incluída na pesquisa.

Entre o final do século XIX e início do século XX, dois nomes se destacam: o Capitão João Venâncio dos Santos e o Capitão Anacleto da Costa Pereira, que iniciam uma rivalidade política que perdura até os dias de hoje. O município de Cuité seria, em termos eleitorais, "dividido ao meio", entre os que seguem os "Venâncio" e o que seguem os "Pereira". O atual prefeito, Charles Cristiano Inácio da Silva, por exemplo, mesmo não sendo de nenhuma das famílias estudadas, teve como vice (entre 2017-2020) Eliú Java Silva Santos Furtado, tendo sido apoiado pelos da Costa Pereira. Ele venceu a eleição de 2016 disputada contra Fabiano Valério de Farias Fonseca, apoiado pelos Venâncio dos Santos, por dissidentes da família Furtado e pelos Simões (ainda que esta última família tenha menor influência política atualmente). Nas eleições de 2016 (como também na de 2020), portanto, mais uma vez as famílias de elite de Cuité se enfrentaram nas eleições municipais.

A disputa política afeta o setor público de cargos comissionados do município e do Estado, que serão indicados e ocupados de acordo com quem detém o poder naquele momento. Por isso, durante o período eleitoral, as famílias e os grupos políticos disputam os votos da população para ter maioria e, assim, demonstrar o seu poder político frente aos seus pares e requerer cargos e "benefícios” para o município.

Ao se observar os quadros do Poder Executivo e Legislativo municipal, verificamos que os membros e os aliados destas famílias de elite alternaram-se durante todo o século XX e XXI nos principais cargos políticos desde 1937, quando o município volta a emancipar-se. As famílias Fonseca, Furtado e Simões vão se aliar, em diferentes momentos, às famílias da Costa Pereira e Venâncio dos Santos, seja por meio de alianças matrimoniais, econômicas ou estritamente políticas.

$\mathrm{Na}$ segunda geração destas famílias, destacam-se: Jeremias Venâncio dos Santos, casado com Francisca Emília da Fonseca Santos e filho do Capitão João Venâncio dos Santos; cujos filhos e netos, noras e genros também participaram da política e protagonizaram o cenário político municipal durante as gerações seguintes. Seus filhos Orlando e sua esposa Neusa Bezerra foram prefeitos; seu filho Osvaldo foi vereador e presidente da câmara; seus genros Rivaldo Silvério da Fonseca, Pedro Bento de Lima e Cláudio Gervásio Furtado foram prefeitos; seu neto Osvaldo Venâncio dos Santos Filho foi vereador, vice-prefeito, prefeito e deputado estadual, e sua esposa, Euda Fabiana Palmeira Venâncio, foi prefeita. Seus netos Péricles Venâncio dos Santos, Max 
Weber Venâncio dos Santos, Giovani dos Santos Furtado foram vereadores em várias legislaturas seguidas; e seu bisneto, Renan Teixeira dos Santos Furtado, foi presidente da Câmara Municipal durante a legislatura 2017-2020, e é atualmente vice-prefeito.

Ao analisarmos os diagramas genealógicos familiares, constatamos que os membros destas famílias de elite ocuparam e ainda ocupam posições dominantes na esfera política, social, econômica e cultural do município de Cuité.

Na Família Fonseca, por exemplo, o primeiro registro que encontramos de ocupação de cargo político (Diagrama $1^{7}$ ), refere-se a Francisco Theodoro da Fonseca, que, em 1899, era Presidente da Municipalidade de Cuité. Neste mesmo ano, seus primos Vicente Ferreira da Fonseca (chefe da estação de arrecadação) e Antônio Francisco da Fonseca (3. Suplente de Juiz) tinham também posições de destaque, registradas no ALMANAK - Administrativo, Mercantil e Industrial do Estado da Parahíba, datado de 1899.

Basílio Magno da Fonseca, filho de Francisco Theodoro da Fonseca e Maximina Leopoldina de Assis Lima, ocupou funções políticas em Picuí e Cuité. Foi nomeado Prefeito Municipal de Picuí em 1932 ; eleito vereador neste mesmo município, em 1935; atuou como $1^{\circ}$. Suplente de Juiz Municipal da Serra de Cuité, entre 1933 e 1941; e foi o primeiro prefeito eleito de Cuité, em 1947, tendo disputado a eleição com João Teodósio da Silva Coelho ${ }^{9}$ (casado com Joana Furtado Coelho, filha de Manoel da Silva Furtado, que dá início à linhagem da família Furtado), ficando no cargo até 1951.

Rivaldo Silvério da Fonseca (filho de Basílio Magno e neto de Francisco Theodoro) também foi prefeito nomeado de Cuité em 1940. Ele era casado com a primogênita de seu primo de $2^{\circ}$ grau, Jeremias Venâncio dos Santos (deputado estadual em 1935 e, também, prefeito nomeado em $1940^{10}$ ), Maria Elita dos Santos da Fonseca. Ele foi ainda desembargador do Tribunal de Justiça da Paraíba e nomeia, por isso, o Fórum instalado na comarca de Cuité. O irmão de Rivaldo, Adauto Augusto da Fonseca, casado com Auta Viana da Costa Fonseca' ${ }^{11}$ (família da Costa Pereira) foi vereador (1951-1955) e seu cunhado, Adauto Soares da Costa, casado com sua irmã Amália Fonseca, foi prefeito nomeado (1944-1945).

A lista de ex-prefeitos de Cuité da família Fonseca é completada por João Venâncio da Fonseca, primeiro prefeito nomeado após a emancipação do município, em 1937 (neto de Antônio

\footnotetext{
${ }^{7}$ Para evitar repetições, não vamos remeter ao Diagrama 1 nos parágrafos seguintes, mas ele é a referência para as informações aqui organizadas.

${ }^{8}$ Neste período, como já mencionado, Cuité pertencia ao município de Picuí.

${ }^{9}$ João Teodósio foi vereador entre 1959 e 1963, em Cuité; tendo sido também delegado e juiz de paz (magistrado, frequentemente sem formação jurídica, que exercia diversas funções judiciais, que variavam dependendo do lugar e época).

${ }^{10}$ Em 1940, sucederam-se três prefeitos nomeados em Cuité.

${ }^{11}$ Filha de Ana Florentina da Costa (filha do Capitão Anacleto da Costa Pereira com Maria Florentina da Costa) e Ulisses Viana Campos (filho de Tomaz Soares da Costa Campos, irmão do Capitão Anacleto).
} 
Januário da Fonseca, tio de Francisco Theodoro da Fonseca; além de filho de Ana Avelina, tia de Jeremias Venâncio dos Santos); e por Benedito Venâncio dos Santos (nomeado prefeito entre 19451946), filho de Joaquim Venâncio dos Santos, tio de João Venâncio da Fonseca. Assim, entre 1937 (emancipação política) e 1951 (quando termina o mandato de Basílio Magno da Fonseca), membros da família só não ocuparam o cargo de prefeito municipal entre 1941 e 1944. Este período demarca a época de maior influência desta linhagem, ainda não separada da família Venâncio dos Santos.

Outros membros da família Fonseca que ocuparam cargos políticos foram: José Bianor da Fonseca, vereador em dois mandatos (1951-1955 e 1969-1972), bisneto de Antônio Januário da Fonseca; Fabiano Valério de Farias Fonseca, vereador entre 2001 e 2004, quando foi presidente da Câmara Municipal, vice-prefeito entre 2005 e 2008, e candidato derrotado a prefeito nas eleições de 2016, sobrinho de José Bianor; e Cleanto Santos Macedo, vereador entre 1972 e 1977, bisneto de Francisco Theodoro da Fonseca.

Temos, portanto, dois ramos políticos da família Fonseca. O primeiro, mais influente, dos descendentes de Francisco Theodoro da Fonseca, e o segundo, dos descendentes de Antônio Januário da Fonseca. Um terceiro ramo, do Capitão João Venâncio dos Santos, formará a linhagem dos Venâncio dos Santos (cf. Diagrama 1 e Diagrama 2). O poder político e econômico da família Fonseca foi assegurado através de uma série de casamentos endogâmicos ${ }^{12}$. Formaram casais, entre outros, os primos: Jeremias Venâncio dos Santos e Francisca Emília da Fonseca, Rivaldo Silvério da Fonseca e Maria Elita dos Santos Fonseca e Adauto Augusto da Fonseca e Auta Viana de Campos Fonseca. O casamento entre primos tem maior recorrência nesta família entre o final do século XIX até meados do século XX. Outra estratégia matrimonial é o casamento de membros da família com pessoas das famílias da Costa Pereira e Furtado, como, por exemplo, Elza Elísia Fonseca dos Santos Furtado (neta de Francisco Theodoro da Fonseca, por parte de mãe e do Capitão João Venâncio dos Santos, por parte de pai), casada com Cláudio Gervásio Furtado, filho de Joana Emília da Fonseca Coelho, prefeito entre 1963-1968 e 1972-1977. O entrecruzamento entre as famílias foi um complicador durante a realização da pesquisa. O casamento de Elsa e Cláudio, por exemplo, é tanto endogâmico (já que eles são primos de terceiro grau na linhagem dos Fonseca) quanto uma aliança entre duas famílias da elite cuiteense.

\footnotetext{
12 Segundo Lewin (1993), os casamentos entre primos nas famílias de elite demonstram como a força de parentes consolidava e mantinha redes de poder econômico e político, e a coesão social do grupo familiar.
} 
Diagrama 1: Linhagem da família Fonseca e ocupação de cargos políticos em Cuité - PB

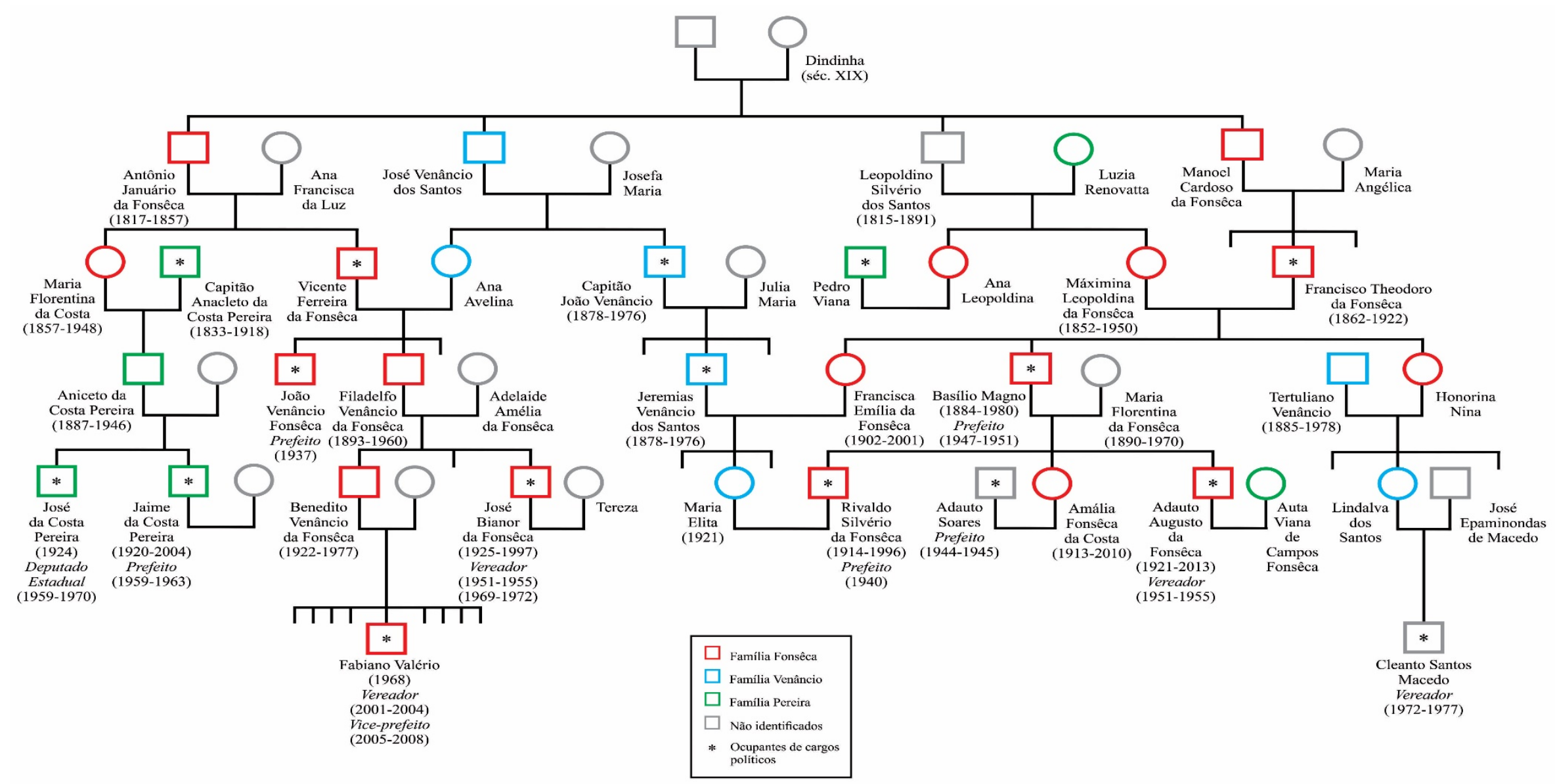

Fonte: Elaboração própria a partir de Pereira Sobrinho $(2001,2008)$, inventários e entrevistas. 
A família Venâncio dos Santos também começa a ocupação de cargos políticos no século XIX, já que Jorge Venâncio dos Santos ${ }^{13}$ aparece em 1899 como Vice-Presidente da municipalidade e, em 1904, como Presidente do Conselho Municipal de Intendência. Seu irmão, o Capitão João Venâncio dos Santos era o delegado de polícia em 1899, como indica o ALMANAK Administrativo, Mercantil e Industrial do Estado da Parahyba, datado de $1899^{14}$.

Dos filhos do Capitão João Venâncio dos Santos (com quem demos início a esta linhagem familiar, cf. Diagrama 2), Jeremias Venâncio dos Santos ocupou cargo como integrante do Conselho de Intendência Municipal por dois mandatos, entre final do século XIX e início do século XX, foi Deputado Estadual em 1935, fundador da Cooperativa de Crédito Rural de Cuité, em 1936, e da Sociedade São Vicente de Paulo, entidade beneficente dedicada à assistência aos pobres ainda hoje existente. Foi ainda prefeito nomeado em 1940.

Os descendentes de Jeremias dos Santos vão, durante décadas, ocupar cargos políticos centrais no município de Cuité como prefeitos, vereadores e presidentes da câmara municipal. Seus filhos ou genros foram prefeitos e vereadores, e seus netos também ocuparam cargos políticos. No século XXI, eles ainda permanecem no poder (Diagrama 2).

Na família Venâncio dos Santos, ocuparam cargos políticos em Cuité, além de Jeremias Venâncio dos Santos: seu filho, Orlando Venâncio dos Santos, como prefeito entre 1955 e 1959; seu primo, Gentil Venâncio dos Santos Palmeira, foi vice-prefeito entre 1963 e 1968, e 1973 e 1977; sua nora, Neusa Bezerra dos Santos (casada com Orlando Venâncio dos Santos), foi prefeita entre 1969 e 1972; seu filho, Osvaldo Venâncio dos Santos, foi vereador entre 1993 e 1996, e 1997 e 2000, foi Presidente da Câmara Municipal nos biênios 1993/1994 e 1997/1998 e candidato derrotado a prefeito nas eleições de 1988; seu neto, Osvaldo Venâncio dos Santos Filho (Bado), foi vereador entre 1989 e 1992, Presidente da Câmara Municipal no biênio 1989/1990, vice-prefeito entre 1993 e 1996, foi prefeito em dois mandatos (1997/2000 e 2001/2004) e deputado estadual suplente, assumindo o mandato durante 123 dias, em 2013; Euda Fabiana de Farias Palmeira Venâncio (esposa e prima de Osvaldo Venâncio dos Santos Filho) foi prefeita entre 2009 e 2012, entre e 2013 e 2016; seu neto, Giovanne dos Santos Furtado, foi vereador entre 1989 e 2008, tendo ocupado a presidência da Câmara Municipal por dois anos; seu neto, Max Weber Venâncio dos Santos (Quinho), é vereador desde 2008; seu neto, Péricles Venâncio dos Santos, foi vereador entre 2001 e 2007, e candidato derrotado por Euda Fabiana de Farias Palmeira Venâncio nas eleições de 2008; seu bisneto, Renan Texeira dos Santos Furtado, é vereador desde 2012 e atual Presidente da Câmara Municipal, com mandato até 2020 (Pereira Sobrinho, 2001; 2008; cf. Diagrama 2).

\footnotetext{
${ }^{13}$ Filho de José Venâncio e Josefa Maria do Nascimento. Irmão do Capitão João Venâncio e de Ana Avelina dos Santos, casada com Vicente Ferreira da Fonseca (cunhado).

14 Almanak Administrativo, Mercantil e Industrial da Província de Parahyba, 1889. Disponível em: http://memoria.bn.br/docreader/DocReader.aspx?bib=313394\&PagFis=17060\&Pesq=paraiba+cuite. Acesso: 30/11/18
} 
Da linhagem de Tertuliano Venâncio dos Santos (assim como Jeremias, filho do Capitão João Venâncio), casado com Honorina Nina (filha de Francisco Theodoro da Fonseca e Maximina Leopoldina da Fonseca), assumiram cargos políticos em Cuité: seu neto, Cleanto Santos de Macêdo, que foi vereador entre 1973 e 1977; seus bisnetos, Eliú Javã Silva Santos Furtado, foi vereador entre 2008 e 2016 e atualmente é o vice-prefeito (2017-2020); e Enos Abdan Silva Santos Furtado é vereador desde 2017 (cf. Diagramas 1 e 2). Ressaltamos, ainda, que, na última eleição municipal, este ramo da família Venâncio dos Santos apoiou Charles Cristiano Inácio da Silva (irmão da primeira esposa de Bado) contra o candidato do casal Bado e Euda, Fabiano Valério de Farias da Fonseca. Entre todas as famílias da elite cuiteense, os Venâncio dos Santos são os que apresentam a maior longevidade em termos de influência na política local. São pelo menos quatro gerações de políticos, distribuídos em três ramos: o principal, dos descendentes de Jeremias Venâncio dos Santos; o ramo dos descendentes de Elisa Etelvina Santos Palmeira, que, como Jeremias, é filha do Capitão João Venâncio dos Santos; e o ramo de Tertuliano Venâncio dos Santos, também filho do Capitão João Venâncio, todos eles nascidos no final do século XIX (Diagrama 2).

Assim, a família Venâncio dos Santos cobre mais de 100 anos na ocupação de cargos políticos em Cuité, sendo provavelmente a mais influente entre elas, no início do século XXI. Os casamentos endogâmicos também eram comuns entre os Venâncio dos Santos. Esta família apresenta um caso mais recente e destacado deste tipo de estratégia matrimonial: Osvaldo Venâncio dos Santos Filho casou com a prima distante, Euda Fabiana de Farias Palmeira Venâncio (cf. DIAGRAMA 2). O casal dominou a política local nas décadas de 1990 e 2000, totalizando quatro mandatos no executivo municipal. 
Diagrama 2: Linhagem da família Venâncio dos Santos e ocupação de cargos políticos em Cuité - PB

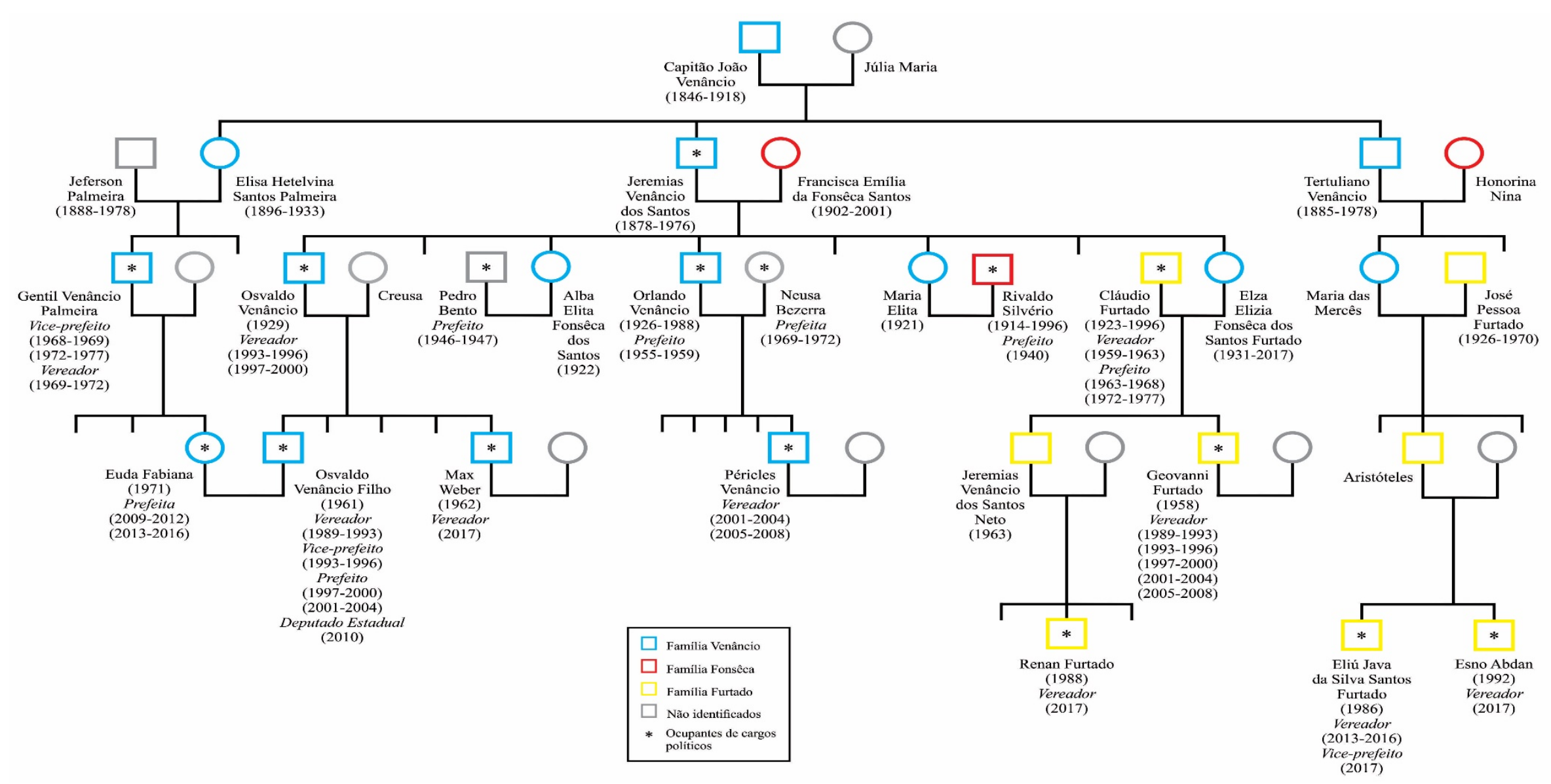

Elaboração própria a partir de Pereira Sobrinho $(2001,2008)$, inventários e entrevistas. 


\section{DIMENSÕES DA PROPRIEDADE DA TERRA}

Ainda que o escopo deste artigo não dê conta de apreender de modo mais sistemático o vínculo das famílias "ilustres" de Cuité com a propriedade da terra e as transformações na estrutura fundiária do município a partir do Século XIX, iremos, neste artigo, estabelecer, a partir de múltiplas evidências, o lugar do controle sobre o acesso à terra como fundamento do poder político destas famílias, ao mesmo tempo que demonstraremos que, nas últimas décadas, dada a dissolução do patrimônio fundiário destas famílias, estas duas dimensões (terra e política) se separam.

No Século XIX, com a mudança na legislação brasileira com a Lei de Terras, a Constituição Federal de 1891 respalda as famílias que tinha patrimônio fundiário a ocuparem espaços sociais, econômicos e políticos. Segundo Rêgo (2008), a transferência de regulamentação da propriedade territorial aos Estados-membros, que promulgaram legislação específica sobre a questão, relacionou-se em profundidade com o fenômeno sociopolítico do coronelismo, transformando-se em elemento essencial no processo eleitoral, permitindo o controle do poder político local, com apoio de autoridades estaduais e federais.

No município de Cuité, as propriedades rurais das famílias estudadas vão sofrendo transformações ao longo século XX e parte destas propriedades não vão permanecer com as famílias destacadas neste artigo. A dissolução do patrimônio fundiário intensificou-se no final do século XX e início do Século XXI para aquelas famílias que ainda eram grandes proprietárias nesta época, permitindo reinvestimentos de capitais em outras atividades ou patrimônios. É possível demonstrar como se deu a dissolução do patrimônio fundiário. Com dados do INCRA e INTERPA, foi possível mostrar como a maior parte do patrimônio fundiário destas famílias foi desagregado, desapropriado ou vendido via Política Nacional de Crédito Fundiário. Também utilizamos dados dos processos de inventários pesquisados no Fórum da cidade de Cuité.

Os inventários são feitos quando existem bens a partilhar. São instrumentos de disposições materiais e contêm além da relação de herdeiros, a avaliação dos bens móveis e imóveis, certidões de negativas, relações de dívidas e petições e despachos de várias naturezas. Contudo, a relação dos bens nem sempre condiz com o patrimônio que o falecido adquiriu. Ao observar os inventários citados, o falecido nem sempre permanecia com o seu patrimônio, era antecipadamente dividido entre os seus filhos ou vendido. O Senhor Claudio Gervásio Furtado, falecido em 1996, deixou nove propriedades ${ }^{15}$ para sua meeira e seus filhos, que totalizavam três mil oitocentos e dezoito hectares. Ao observar as propriedades da família (QUADRO 1), é possível identificar três propriedades com mais de mil hectares, contudo, com a morte de seu genitor, os filhos venderam parte das propriedades via PNCF e para particulares.

\footnotetext{
${ }^{15}$ Dados do inventário divergem dos dados do cadastro do INCRA acima mencionados.
} 
Quadro 1 - Relação das propriedades rurais de Cláudio Gervásio Furtado

\begin{tabular}{|l|r|c|}
\hline \multicolumn{1}{|c|}{$\begin{array}{c}\text { Relação de bens imóveis rurais (dados retirados do } \\
\text { inventário do falecido) }\end{array}$} & Tamanho (ha) & Localização/Município \\
\hline Uma propriedade denominada Fortuna & $1.408,80$ & Cuité -PB \\
\hline Uma propriedade denominada Alegre & $2.058,00$ & Cuité-PB \\
\hline Uma propriedade denominada União & 126,50 & Cuité-PB \\
\hline Uma propriedade denominada Pontal & 20,00 & Picuí-PB \\
\hline Uma propriedade denominada Sítio Novo & 23,00 & Picuí-PB \\
\hline Uma propriedade denominada Lagoa do Junco e Taburá & 48,40 & Picuí-PB \\
\hline Uma propriedade denominada Estrondo & 60,00 & Nova Floresta-PB \\
\hline Uma propriedade denominada Bela Vista & 9,0 & Cuité-PB \\
\hline Uma propriedade denominada Tamanduá & 65,00 & Cuité-PB \\
\hline
\end{tabular}

Fonte: Elaboração própria com dados retirados do processo de inventário de Cláudio Gervásio Furtado

No processo de inventário de Pedro Simões Pimenta, as propriedades rurais informadas eram: uma propriedade denominada Jardim, com seiscentos hectares; uma propriedade denominada União, medindo trezentos hectares, e uma propriedade localizada no subúrbio da cidade, medindo dois hectares, todas localizadas no município de Cuité, somando novecentos e dois hectares. Contudo, segundo o próprio Senhor Pedro Simões Pimenta, em seu livro O Diário de Vovô Pedro, ele tinha adquirido diversas propriedades, que já não lhe pertenciam na sua morte devido ao adiantamento de herança ou venda das propriedades, de modo que não constavam nos autos processuais de seu inventário.

De acordo com os dados retirados da Série histórica por grupo de área total dos Censos Agropecuários de 1960, 1970, 1975, 1980, 1985, 1995/1996 e 2006 (Gráfico 1), é perceptível que o número de estabelecimentos só aumentou no decorrer dos anos, com exceção para o censo realizado em 1985. Ao mesmo tempo, neste período, cai a área ocupada pelos estabelecimentos acima de 500 ha. E cresce a área ocupada pelos estabelecimentos até 100 ha (Gráfico 1).

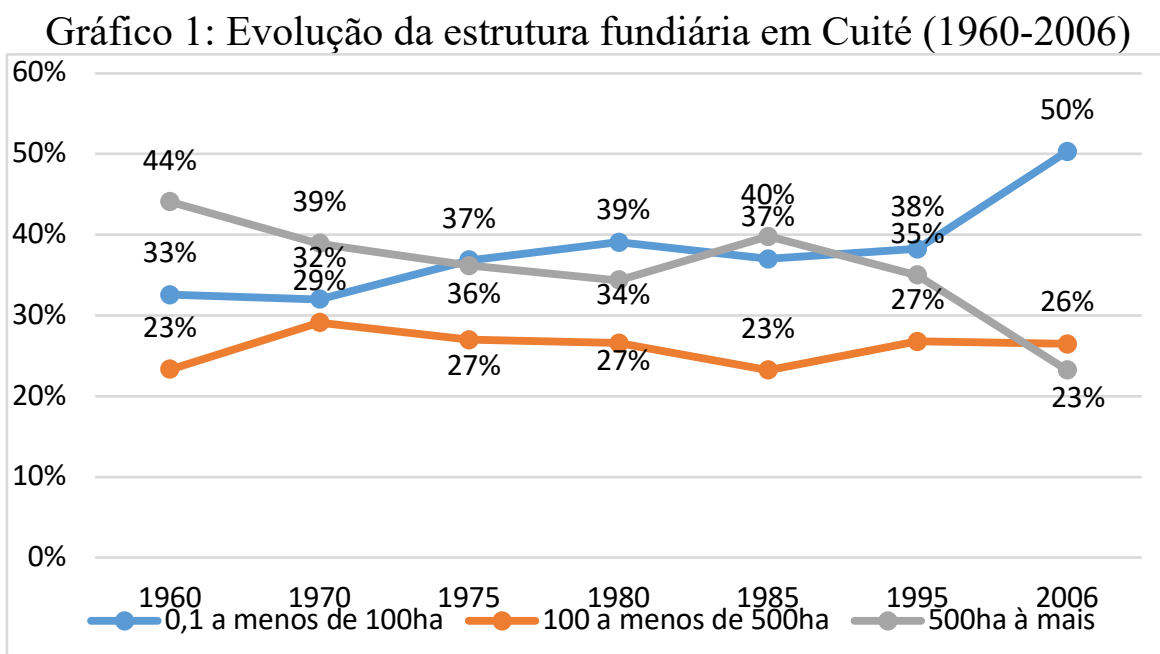

Fonte: Autoria própria. Construído com os dados Censo Agrícola de 1960 e Censos Agropecuários 1970, 1975, 1980, 1985, 1995/1996 e 2006. 
Em 2006, a área ocupada pelos estabelecimentos com até 100 hectares havia subido; totalizando $50 \%$ da área total; a área ocupada pelos estabelecimentos entre 100 e 500 ha sofreu pequenas alterações, ficando com 26\%; e o grupo de propriedades com 500 ou mais hectares, que ocupava 44\% do total em 1960, teve sua participação reduzida, estando limitada então à pouco mais da metade, 23\% (Gráfico 1). A partir de 2006, porém, sabemos que a participação nas propriedades acima de 500 ha continuou a cair, principalmente sob o efeito das aquisições feitas via crédito fundiário.

A dissolução do patrimônio fundiário atinge seu ponto máximo já no Século XXI, com a criação do Programa Nacional de Crédito Fundiário. O motivo para que os proprietários comercializassem suas terras via PNCF são diversos: alguns alegam o longo período de estiagem, outros são herdeiros e não mais residem no município; o "problema" das leis trabalhistas; dentre outros apresentados pelos proprietários em entrevistas realizadas no ano de 2017. Ao ser perguntado como ele percebia este processo de venda da terra, o Senhor Giovanni Santos Furtado respondeu que

\begin{abstract}
(...) o problema é o seguinte hoje em dia ninguém quer trabalhar, no tempo do seu avô e de seu pai a gente pagava uma pessoa pra trabalhar não precisava nem olhar, ele trabalhava, ele produzia, entendeu, a honestidade era muito grande naquele tempo, hoje em dia é o seguinte: você paga um dia de serviço a um trabalhador daquele, depois você vai olhar o que ele trabalhou dá duas horas de serviço. Depois vem a questão trabalhista, você bota uma pessoa pra trabalhar passa dois, três, quatro cinco, seis, anos depois já quer entrar na justiça, já quer tomar os seus troços, isso aí é o pior, talvez melhore com essa reforma, realmente é isso aí. (Giovanni dos Santos Furtado, entrevistado em 15/07/2017).
\end{abstract}

Perguntado sobre os bens e se investiram fora do mundo rural, relatou que:

(...) meu pai morreu aí teve a divisão pra minha mãe, pra os cinco, e aí a gente foi vendendo e transformando em outra coisa, apartamento em Campina e outras coisas, coisas que dá mais lucro né.

- Vocês foram investindo fora?

Fora. Pronto, eu comprei um apartamento em Campina tal e aí Suzana comprou também, aí

Cláudia comprou também e Ângela comprou também tal, a gente transformou em outra renda. (Giovanni dos Santos Furtado, entrevistado em 15/07/2017).

Ao analisarmos a fala do entrevistado e comparar com os dados fornecidos na lista de operações de crédito fundiário em Cuité, no período de 2003 a 2007, pudemos constatar que o patrimônio foi sendo vendido e os recursos assim adquiridos investidos em outras atividades.

Alguns dados do Governo Estadual da Paraíba fornecidos pela Secretária de Estado do Desenvolvimento do Agropecuário e da Pesca e pelo Instituto de Terras e Planejamento Agrários referentes ao Programa Nacional de Crédito Fundiário mostram que várias propriedades 
pertencentes a grandes proprietários foram vendidas e transformados em assentamentos rurais. No município de Cuité, foram trinta e quatro operações via PNCF entre 2003 e 2007.

$\mathrm{Na}$ lista de operações de crédito fundiário em Cuité, no período de 2003 a 2007, existiam várias propriedades que pertenciam aos herdeiros de Cláudio Gervásio Furtado (Fazenda Alegre, Fortuna I e II e Fortuna III, total de 1.582,59 hectares) e da família Simões (Fazenda Tanques, Fazenda Jardim, total de 722,52 hectares), que foram vendidas por meio do Programa de Crédito Fundiário para estabelecer assentamentos rurais.

Estas famílias eram proprietárias de terras no final do século XIX e ao longo do século XX. A propriedade da terra, porém, não explica totalmente o domínio político, já que, nas últimas décadas, como demonstramos, suas propriedades têm sido divididas, vendidas ou desapropriadas para fins de reforma agrária. A dissolução do patrimônio fundiário, contudo, não dilapidou o capital simbólico/eleitoral destas famílias.

Só o capital econômico, portanto, é insuficiente para explicar o sucesso eleitoral. O nome da família se converte num capital político e simbólico, ativado a cada quatro anos nas disputas municipais. Na verdade, terminadas as eleições, as rivalidades permanecem, através de uma série de recursos políticos (cargos e favores, principalmente) que são permanentemente disputados.

As disputas eleitorais no município de Cuité permanecem, portanto, atreladas às famílias tradicionais e a suas rivalidades. Contudo, entre rupturas e permanências, não é possível desconsiderar as transformações recentes no cenário político, social e econômico do país e da região. Processos de modernização ressignificam permanentemente a influência política destas famílias, que precisam mudar suas estratégias eleitorais e suas alianças.

\section{O MOVIMENTO DIASPÓRICO DOS HERDEIROS}

Procuramos demarcar as linhas gerais do processo de deslocamento dos membros das principais famílias que compuseram, no século $\mathrm{XX}$, a elite em Cuité (PB), que chamamos de diáspora, entendida como um processo que redefine a dinâmica social, cultural e histórica do pertencimento, referindo-se à perda progressiva dos laços de alguns dos descendentes das famílias Fonseca, Furtado, da Costa Pereira e Venâncio dos Santos, com a cidade de Cuité.

O deslocamento do sujeito diaspórico e sua condição produzem estranhamento, lembranças e indagações que envolvem, ao mesmo tempo, a relação do migrante com sua cidade de origem e com seu novo lar e a busca por uma identidade cultural. Mesmo que tradicionalmente o termo diáspora seja empregado para situações de grupos sociais subalternos, não é incomum sua utilização para falar de deslocamentos de membros da elite social. Guimarães (2002), por exemplo, chamou de diáspora o deslocamento de pesquisadores brasileiros na década de 1990. Gardner (2008) 
nomeou de diáspora o deslocamento transnacional de membros da elite indiana (classes médias e altas) e como suas vivências e estratégias se diferenciam dos migrantes indianos das classes mais pobres.

A diáspora dos membros das famílias de elite de Cuité ganha significado junto ao processo paralelo de dissolução do patrimônio fundiário, que expressa, por sua vez, processos sociais mais gerais, fazendo com que outras profissões sejam buscadas, normalmente associadas a algum tipo de formação superior. Buscamos descrever e analisar a diáspora dos descendentes das famílias de elite a partir da construção de árvores genealógicas que indicam o lugar de residência atual e a profissão dos membros das famílias e de entrevistas realizadas com estes sujeitos diaspóricos que estão hoje com idade acima de 50 anos. Em suas narrativas, eles combinam memórias da infância em Cuité e também suas experiências posteriores, como residentes em outras localidades. Escolhemos trabalhar com este grupo justamente por esta situação de liminaridade. Seus filhos, por outro lado, ainda que possam manter algum tipo de vínculo com Cuité, nunca residiram na cidade.

Dos descendeste de Basílio Magno da Fonseca, o nome mais destacado foi o de Rivaldo Silvério da Fonseca, já falecido, casado com a primogênita de Jeremias Venâncio dos Santos, Maria Elita, que atualmente nomeia o Fórum da comarca de Cuité. Rivaldo foi prefeito e também desembargador do Tribunal de Justiça da Paraíba. Suas duas filhas residem atualmente em Campina Grande (PB): Eliana Marta dos Santos Fonseca, graduada em direito e procuradora aposentada, e Jaqueline Santos da Fonseca Almeida Gama, professora na Universidade Estadual da Paraíba. Todos os netos de Rivaldo nunca residiram em Cuité. Maria Anita da Fonseca Limeira, também filha de Basílio Magno, teve dois filhos, Cláudio Limeira, residente em João Pessoa, e Marília Fonseca, residente em Cuité, assim como sua filha e seus netos. Já Amália Fonseca da Costa, falecida em 2010, foi casada com Adauto Soares da Costa, ex-prefeito nomeado de Cuité, e teve cinco filhos: Marlene, Maria Cristina, Marie, Maurício e Mário. Destes, todos fizeram sua vida profissional fora de Cuité: três em João Pessoa, como servidores públicos, um em São Paulo, como contador, e outro em João Pessoa, como servidor público. Entre os outros descendentes de Basílio Magno, há aqueles que residem ainda em Cuité, destacando-se alguns dos filhos de Clóvis Clodomiro da Fonseca, em cujas estratégias não se destacam os investimentos na aquisição de capital cultural. Por outro lado, não estão também envolvidos diretamente na vida política do município.

Dos filhos de Cláudio Gervásio Furtado (cinco ao total), dois ainda residem em Cuité (Jeremias e Giovanni), enquanto as três filhas (Ângela, Suzana e Cláudia) residem em Brasília e Campina Grande. Tivemos a oportunidade de entrevistar seus cinco filhos. Nesta família, a estratégia do investimento em capital cultural é mais destacada justamente entre a descendência feminina. Ângela e Cláudia são médicas. Suzana graduou-se em fisioterapia e é professora da 
Universidade Estadual da Paraíba. Estas três filhas deram a Cláudio Furtado sete netos, todos eles residentes fora de Cuité: dois médicos, dois odontólogos, um arquiteto, um advogado e um turismólogo. Dos filhos homens, são seis netos, dos quais três ainda residem em Cuité. Entre esses seis netos, há um médico, um engenheiro, um odontólogo e dois bacharéis em direito. Assim, dos 13 netos de Cláudio Furtado, 10 residem atualmente em outras cidades.

A família da Costa Pereira expressa o caso diaspórico mais exemplar. De todos os descendentes de Jaime da Costa Pereira (10 filhos e 28 netos), apenas dois residem atualmente em Cuité: uma filha e um neto. Repete-se, entre eles, a estratégia do deslocamento associado à busca por educação formal. Entre os 10 filhos, encontramos: dois médicos, dois engenheiros, uma farmacêutica, duas bancárias (sendo uma delas formada em direito), uma dona de casa, uma odontóloga e um consultor em piscicultura.

\section{CONSIDERAÇÕES FINAIS}

Ao longo deste trabalho, buscamos retomar o debate acerca das relações entre propriedade da terra e poder político no interior do Nordeste a partir de uma nova perspectiva, que considerou principalmente a dissolução do patrimônio fundiário das famílias da elite do município de Cuité, localizado no Curimataú da Paraíba, e o processo de deslocamento dos descendentes das famílias Venâncio dos Santos, Pereira, Fonseca, Furtado e Simões, que gradativamente perdem os vínculos com o espaço rural e mesmo com a vida social da cidade de origem, processo esse que chamamos de movimento diaspórico.

É importante neste momento destacar alguns dos “dilemas da herança” recebida pelos descendentes das famílias da elite cuiteense: a) como buscamos demonstrar, a herança da terra é um ativo a ser convertido em outros bens econômicos. Se a memória destes descendentes ainda se constitui em torno da propriedade da terra dos pais e das atividades agropecuárias que ali eram executadas; se, mesmo no presente, para alguns dos descendentes, a fazenda herdada resiste como lugar de sociabilidade e moradia, a propriedade da terra deixa de ser central na reprodução social e econômica destes indivíduos, convertidos à vida e profissões urbanas. Assim como demonstrou Meneses (2018), para famílias de elite do Cariri paraibano, as fazendas se tornam, quando ainda mantidas, lugares de celebração da memória familiar. Outros descendentes, porém, cortaram completamente os laços com o passado rural; b) a relação com a herança política é mais problemática. Mesmo com o movimento diaspórico, as disputas políticas continuam a mobilizar os descendentes das famílias de elite. A grande maioria não se envolve diretamente nos processos eleitorais, mas a rede de apoios, os capitais políticos historicamente acumulados, são reativados em diferentes situações, especialmente em relação à ocorrência das eleições municipais. Antigas rivalidades e alianças históricas podem ser reavaliadas, mas, para muitos dos descendentes das 
famílias Venâncio dos Santos, Pereira, Furtado, Fonseca e Simões, é impossível simplesmente manter-se indiferente às disputas na cidade de suas famílias. Isso ocorre principalmente na geração nascida em Cuité a partir da década de 1950, que experimentou a migração para centros urbanos maiores. Seus filhos e netos, porém, não apresentam a mesma disposição e; c) essa relação com a política, porém, não é a mesma para aqueles que permaneceram em Cuité. Os descendentes não diaspóricos normalmente se vinculam mais diretamente aos processos eleitorais e continuam a disputar poder e prestígio. Nas eleições municipais de 2016, um membro da família Fonseca, apoiado pelos Venâncio dos Santos, foi derrotado na disputa para prefeito, por um candidato cujo vice-prefeito é da família Furtado, apoiado pelos da Costa Pereira. Dos 11 vereadores eleitos nesta disputa, dois são da família Furtado e um da família Venâncio dos Santos, sendo que dois deles com idade inferior a 30 anos, o que expressa a renovação política nestas linhagens. O atual presidente da Câmara Municipal é um Furtado.

Duplamente desterritorializados (da propriedade da terra e da cidade de origem), muitos dos descendentes das famílias da elite cuiteense mantêm uma relação ambígua com o lugar em que nasceram. Se a história familiar em Cuité é ainda fonte importante dos esforços de ancorar no passado o sentido de distinção pessoal e familiar, há também um reforço em novas formas de identificação social. Desenvolveram suas carreiras profissionais sem qualquer conexão com o passado agrário e político de suas famílias.

Há, porém, os que ainda residem na cidade e que continuam a disputar influência política. E linhagens menos influentes no passado das mesmas famílias passam a ocupar lugar de maior destaque na vida política e econômica do município, num quadro de maior complexidade econômica e institucional, resultantes dos processos de modernização e de transformação social vividas na região, como reflexo das transformações mais gerais vivenciadas no Brasil entre finais do século XX e início do século XXI.

Do ponto de vista do debate mais geral, acreditamos que este artigo permite analisar as relações entre propriedade fundiária e poder político no interior do Nordeste em termos menos determinísticos. De certa maneira, este trabalho é herdeiro da obra seminal de Lewin (1993) e integra os esforços de um grupo de pesquisadores do PPGCS/UFCG no sentido de considerar as transformações na estrutura fundiária e os processos de modernização mais amplos para refletir sobre o poder político nesta região. A história das famílias de elite de Cuité mostra que a conversão de capital econômico e político em capital cultural foi a estratégia dominante entre linhagens proeminentes a partir da década de 1950. Os filhos dos líderes políticos, personagens até os dias de hoje exaltados, foram socializados não para a terra ou para a política, mas para o exercício de profissões liberais em centros urbanos mais desenvolvidos. 


\section{REFERÊNCIAS BIBLIOGRAFICAS}

BOTTERO, W. STRATIFICATION - Social division of inequality. Routledge, Nova York - NY. P3, 2005.

BOTTERO, W. Who do you think they were? How family historians make sense of social position and inequality in the past. The British Journal of Sociology, v. 63 n. 1. p.55, 2012.

BOURDIEU, P. Razões Práticas - Sobre a teoria da ação. $9^{\mathrm{a}}$ ed., Campinas (SP): Papirus Editora, 1996.

FURTADO, C. Uma política de desenvolvimento econômico para o Nordeste. 2. ed. Recife: SUDENE, 1967.

GARCIA JR., Afrânio. Os vice-reis do Norte: reconversão de elites agrárias e a Revolução de 1930 (1920-1964). Revista de Ciências Sociais, v. 38, n. 02, p. 73-87, 2007.

INTERPA- Instituto de Terras e Planejamento Agrícola do Estado da Paraíba.2007.

INCRA. Instituto Nacional de Colonização e Reforma Agrária - Relação de Certificados de Cadastro de Imóveis - CCIR. Brasília, 1992.

KLÜGER, E. Espaço social e redes: Contribuições metodológicas à sociologia das elites. Tempo Social, v. 29, n. 3, p. 83-110, 2017. https://doi.org/10.11606/0103-2070.ts.2017.125961

LEWIN, Linda. Política e parentela na Paraíba: um estudo de caso da oligarquia de base familiar. Rio de Janeiro: Record, 1993.

MAIA, K. O "agronegócio sertanejo": (re)pecuarização e grande propriedade rural na microrregião de Catolé do Rocha (PB), semiárido nordestino. Campina Grande, 2013. Tese de Doutorado apresentada no Programa de Pós Graduação de Ciências Sociais (PPGCS) da Universidade Federal de Campina Grande (UFCG), 2013.

MENEZES. Saudade e Rusticidade: reconversões sociais e convivência com as secas entre elites pecuaristas do Cariri paraibano. Rio de Janeiro, 2018. Tese de Doutorado apresentada no Programa de Pós Graduação de Ciências Sociais em Desenvolvimento, Agricultura e Sociedade da Universidade Federal Rural do Rio de Janeiro, 2018.

MONTEIRO A política como negócio de família: os herdeiros e a força dos capitais no jogo político das elites na Paraíba (1985-2015). Campina Grande, 2016. Tese de Doutorado apresentada no Programa de Pós Graduação de Ciências Sociais (PPGCS) da Universidade Federal de Campina Grande (UFCG), 2016.

NUNES, A. M. Dinâmicas de fronteira e conformação das estruturas social e fundiária nos sertões da Borborema entre os séculos XVIII e início do século XX. Campina Grande, 2016. Tese de Doutorado apresentada no Programa de Pós Graduação de Ciências Sociais (PPGCS) da Universidade Federal de Campina Grande (UFCG), 2016.

PEREIRA SOBRINHO, J. P. Cuité Terra Nossa. Cuité - PB: Edição Particular, 2001.

PEREIRA SOBRINHO, J. P. Cidadão da Minha Rua. Campina Grande: Gráfica Vitória, 2005.

PERISSINOTO, R. M.; CODATO, A. Apresentação: por um retorno à Sociologia das Elites. Revista de Sociologia e Política, v. 16, n. 30, p. 7-15, 2008. https://doi.org/10.1590/S010444782008000100002

PERISSINOTTO, R. As elites políticas: questões de teoria e método. Curitiba: Ibepx, 2009.

REGO, A. H do. Família e Coronelismo no Brasil - uma história de poder. São Paulo: A Girafa editora, 2008. 
SAINT MARTIN, M. Da reprodução às recomposições das elites: as elites administrativas, econômicas e políticas na França. TOMO São Cristóvão - SE No 13 jul./dez. 2008.

SCOTT, J. Sociologia: conceitos-chave. Rio de Janeiro: Zahar, 2010. 